\title{
Fokus na pokus
}

\author{
Karolina Dvojković, Sanja Pavlović Šijanović, Kristina Kristek \\ Gimnazija Vukovar \\ Šamac 2, 32000 Vukovar \\ karolina.dvojkovic@skole.hr,sanja.pavlovic-sijanovic@skole.hr,kristina.kristek@skole.hr
}

\section{Sažetak}

Prirodni procesi idealni su primjer za provođenje nastave usmjerene prema djelovanju koja daje učenicima mogućnost preuzimanja inicijative u učenju gdje radoznalost, kreativnost i eksperimentiranje s idejama nadmašuju zacrtani plan tradicionalne nastavne teme. Ako se u cijeli proces uključe interdisciplinarnost $i$ informacijsko - komunikacijske tehnologije, teorijski koncepti postaju realistični, učenicima olakšavaju razumijevanje realnih događanja kojima svjedoče svaki dan. U našoj svakodnevici promatramo i doživljavamo stanja flore i faune kroz osjetila za miris, sluh, vid itd. Međutim, postoji mogućnost dokazivanja da se mogu doživjeti i druge informacije u našoj okolini. Paralelnim snimanjem i bilježenjem u vidljivom i infracrvenom spektru dobivamo dvostruke informacije naše okoline. Kako izgledaju objekti i priroda u bliskom infracrvenom spektru? Informacije koje nose objekti, biljke i živa bića u bliskom infracrvenom spektru moguće je usporediti sa doživljajem u spektru kojega percipira naše oko. Postoji korelacija refleksije svjetla između vizualne i infracrvene apsorpcije. Razlika vizualne i infracrvene apsorpcije svjetla na flori i fauni omogućuje kamuflaže u kretanju i u okolišu. Skrivanje u flori i fauni posebno je zanimljivo. U radu pokazujemo sinkroniziranu interdisciplinarnost i primjenu tehnologije u odgojno - obrazovnom procesu u kojemu se uspostavlja odnos sa "stvarnim životom", životnim okruženjem učenika, uzajamnom povezanosti stvari u životu sa svim ostalim aspektima određene znanosti, discipline ili predmeta, a rezultat je aktivnosti koje u sinergiji provode učenici prirodoslovno-matematičkog usmjerenja i nastavnici.

Ključne riječi: vidljivi i infracrveni spektar, digitalna fotografija, interdisciplinarnost, prirodoslovlje.

\section{Uvod}

Učenje i poučavanje u prirodoslovlju ima za cilj stjecanje prirodoznanstvene pismenosti odnosno kompetencija koje vode u znanstveni način razmišljanja što učeniku treba omogućiti kompetentnu uporabu stečenih znanja, vještina i stavova u svakodnevnom životu, radu i novim izazovima. Suvremeni kurikulum nas upućuje na problemski i istraživački usmjerenu nastavu (MZO, 2017). Najbolje primjere za bilo koji segment aktivnog učenja u prirodoslovlju pronalazimo upravo u prirodi. Teme iz stvarnoga svijeta i povezanost sa životnim iskustvima, interesima, očekivanjima i znanjima te široka izbornost sadržaja, mjesta i metoda poučavanja potiču interes i motivaciju učenika (MZO, 2017).
Problemski i istraživački usmjerenom nastavom prirodoslovlja pretvaramo pasivnog učenika slušača $i$ gledača u aktivnog istraživača. Navedenim pristupom učenik ima priliku naučiti sustavno istraživati, kritički promišljati i stvaralački primjenjivati. Važno je da učenici znanja, vještine i kompetencije stječu, usvajaju, formiraju i izgrađuju vlastitom aktivnošću. Suvremena istraživanja upućuju na poražavajuće rezultate praćenja aktivnog promišljanja učenika tijekom nastavnog procesa (Conklin, 2007). Analize pokazuju da tijekom jednog sata učitelj učenicima postavi i do osamdeset pitanja dok učenici tijekom istog vremenskog razdoblja postave samo tri pitanja. Za zapitati se je što je uzrokom takve situacije i na koji način je promijeniti? Uzrok je nepoticajan nastavni proces. A kako ga promijeniti? Svaka promjena kreće 
od osobe same, u ovom slučaju nastavnika, a reflektira se na cijeli nastavni proces. Izvrsno osmišljeni planovi i programi nastavnog predmeta nisu svrhoviti ako nisu otvoreni prema učenju. Učenje bi trebalo planirati iz perspektive učenika, a interdisciplinarnim i multidisciplinarnim pristupom učenju i poučavanju omogućiti učenje u stvarnom životu koje integrira $i$ povezuje različita područja razvoja i daje novu kvalitetu učenju. Učenje kao proces treba biti usmjereno na aktivnosti koje u sinergiji provode nastavnik i učenici, pri čemu učenici imaju slobodu riješiti problem na način kako oni to žele, a nastavnik usmjerava na strategije koje će se koristiti. Zašto nije dovoljno prezentirati teorije samo u završnom obliku? Za razvoj znanstvenog znanja učenika bitan je kontekst otkrića i invencije koji uključuje nastajanje i evoluciju ideja. Znanost se karakterizira kao proces otkrivanja i konstruiranja znanja (Krsnik, 2008). Ako nastavnik/mentor želi razvijati prirodoznanstvene kompetencije učenika (sposobnost prepoznavanja i postavljanja istraživačkih pitanja, postavljanja hipoteza, planiranja i provođenja istraživanja, donošenja argumentiranih zaključaka i ideja za nova istraživanja itd.) mora ovladati određenim logičkim vještinama, kako za razumijevanje učenikovih sposobnosti, tako i razumijevanja smisla svog poziva (Žarnić i sur., 2002).

Cilj je ovog rada prikazati razvoj ideje o svjetlosti i boji kroz problemski i istraživački usmjerenu projektnu nastavu prirodoslovlja u srednjoj školi s dominantnijim naglaskom na fiziku te pritom izbjeći usvajanje sadržaja na razni definiranja i reproduciranja, parcijalno po predmetima. Nastavni sadržaji fizike i općenito prirodoslovlja uglavnom su najčešće produkti znanosti u konačnom obliku. lako su sadržaji nastave prirodoslovlja unaprijed određeni to ne znači da se ne mogu napraviti određeni pomaci. Nastavne teme prirodoslovlja nikako ne bi trebale biti bezbojne, već baš suprotno tome, aktivne, otkrivačke, konstruktivne i inventivne. Osim otkrivačkog konstruktivizma treba prevladavati ideja učiti u dubinu na račun širine. Ovaj rad je primjer evolucije jedne fizičke ideje o svjetlosti, boji i elektromagnetskom zračenju, koja se razgranala na neka nova srednjoškolskim učenicima neistražena područja. Uvodna zanimljiva i motivirajuća problemska situacija potiče učenika/e da postane angažirani istraživač koji na temelju poznatoga otkriva nepoznato, istražujući kritički promišlja i stvaralački primjenjuje.

\section{Istraživanje vidljivog i „nevidljivog“}

Ako se pobliže promotri cijeli elektromagnetski spektar uočava se da dio spektra koji se jednim dijelom preklapa $s$ vidljivim dijelom pripada infracrvenom zračenju, slika 1.

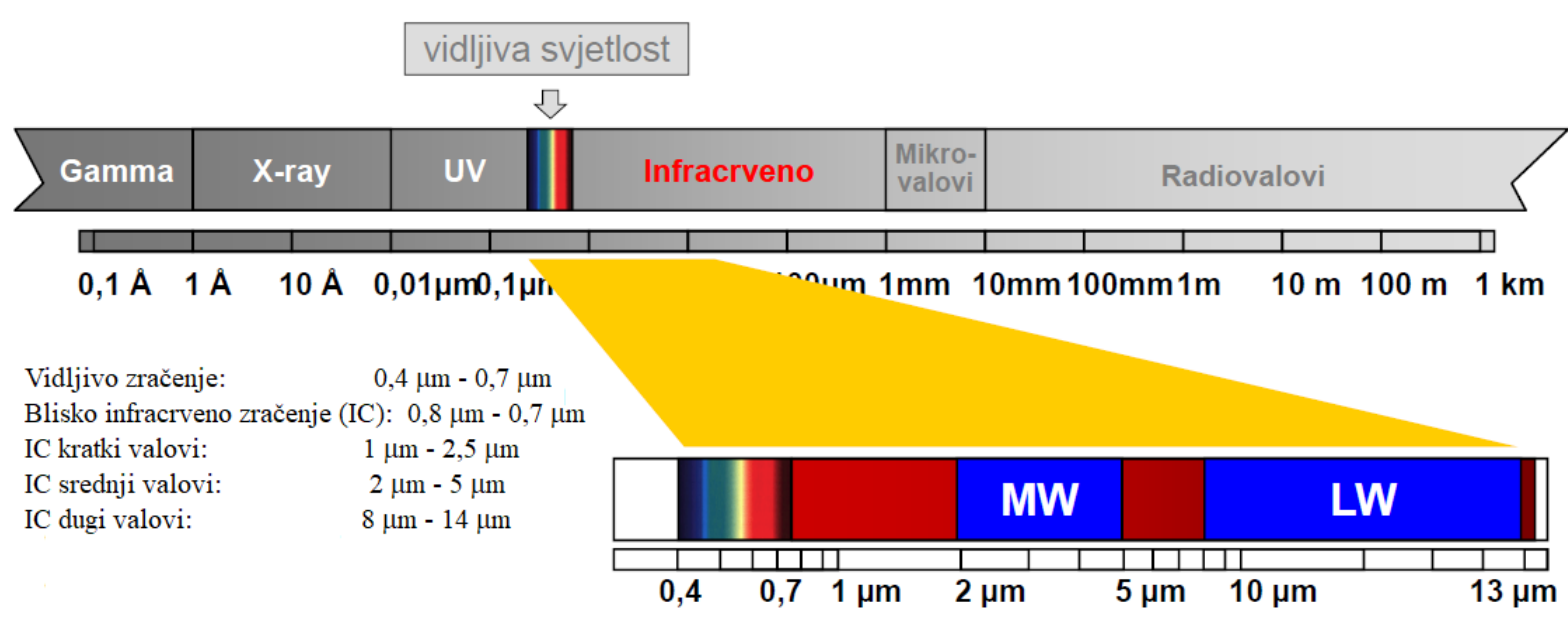

Slika 1. Prikaz elektromagnetskog spektra

Oku vidljivi dio spektra zračenja obuhvaća valne duljine u rasponu od $0,4 \mu \mathrm{m}$ do $0,7 \mu \mathrm{m}$ gdje započinje infracrveno područje, slika 1. Predviđenim nastavnim sadržajima iz fizike fokus se stavlja na istraženi i poznat vidljivi dio spektra elektromagnetskog zračenja (HenčBartolić i Kulušić, 1991; MZO, 2019). Ovo je ključni trenutak intervencije prelaska s pasivnog produkta znanja na aktivni konstruktivizam. Umjesto uvriježenog frontalnog pristupa nastavnika tijekom kojeg učenik samo sluša i gleda, učenika se potiče i podučava za samostalno istraživanje. U ovoj ključnoj fazi odgovori na postojeća pitanja rezultiraju novim pitanjima, a radom u skupini ostvaruju se načela aktivnog učenja (Dimić Vrkić, 2007).

Da bi infracrveno zračenje postalo vidljivim potrebna je pretvorba u neki drugi oblik energije koja se odvija u infracrvenim uređajima uz uporabu raznih detektora. Za snimanje u vidljivom dijelu spektra 
učenici su se koristili običnim digitalnim fotoaparatom, a za snimanje digitalne fotografije $u$ infracrvenom dijelu spektra koristili su posebno modificirani digitalni fotoaparat, Fuji FinePix S5500 i posebno infracrveno osvjetljenje. $U$ ovom dijelu provođenja problemsko-istraživačke projektne nastave učenici se kooperativno bave zajedničkim problemom zalazeći u neistraženo i "nepoznato“ područje.

\section{Modifikacija fotoaparata}

Digitalni fotoaparat koristi senzore slike za „hvatanje podataka o slici“. U fotoaparatu Fuji FinePix S5500 korištenom za provođenje ovog istraživanja to je CCD senzor (Charge Coupled Device). Uloga senzorskih elemenata je pretvorba svjetlosti u napon proporcionalan njenom sjaju; taj se napon onda propušta kroz analogno-digitalni konverter koji prevodi fluktuacije u CCD uređaju u diskretni binarni kôd, slika 2. Digitalni izlaz analogno-digitalnog konvertera se šalje u digitalni procesor signala DSP (Digital Signal Processor) koji podešava kontrast i detalje te komprimira sliku prije nego što je uputi $u$ memorijski medij. Slika dobivena na ovaj način se naziva digitalna fotografija. Što je intenzitet svjetlosti, koja pada na senzor, veći to je napon viši i odgovarajući piksel je svjetliji.

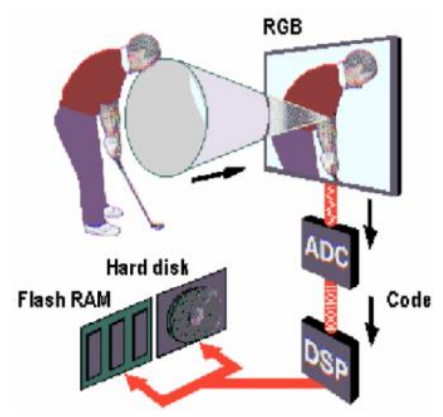

Slika 2. Proces nastajanja slike u digitalnom fotoaparatu

CCD senzor je osjetljiv na valne duljine od $400 \mathrm{~nm}$ do $1100 \mathrm{~nm}$ (vidljivi dio spektar i infracrveno područje), a najosjetljiviji je u području od $800 \mathrm{~nm}$ (infracrveno područje), slika 3.

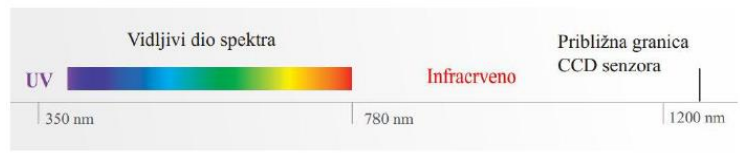

Slika 3. Područje osjetljivosti CCD senzora

Zbog toga CCD senzor ima poseban filter koji blokira informacije iz infracrvenog područja koje dolaze od okoline koja se snima (Bertman, 1970; Šipuš i sur., 2014). Važno je znati da sva tijela koja imaju temperaturu veću od apsolutne nule zrače toplinsku energiju u vidu elektromagnetskog zračenja, u ovom primjeru to je infracrveno područje (zbog temperature). Prevedeno na jezik fizike, Wienov zakon daje vezu između temperature i valne duljine na kojoj se nalazi maksimum energije zračenja.

$$
\lambda_{\text {max. }} \cdot T=2898 \mu \mathrm{mK}
$$

$\lambda_{\text {max. - valna duljina na kojoj se nalazi maksimum }}$ energije zračenja

$T$ - temperatura na kojoj se nalazi maksimum energije zračenja

Modifikacija digitalnog aparata se vrši na način da se iz unutrašnjosti fotoaparata ukloni unutarnji filter, na CCD senzoru, koji blokira infracrvenu svjetlost, što su učenici i učinili, slika 4.

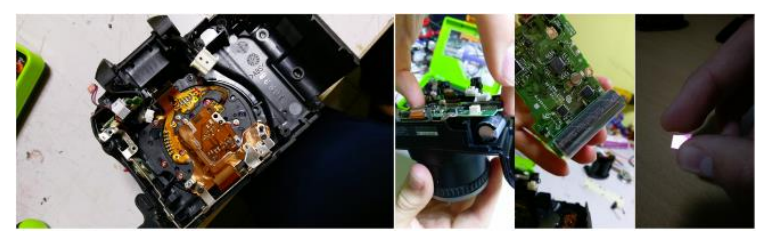

Slika 4. Odstranjivanje unutarnjeg filtera, blokatora IR zračenja, sa CCD senzora digitalnog fotoaparata

Nakon uklanjanja unutarnjeg filtera iz fotoaparata, isti se više ne može koristiti za klasične vrste fotografija, tj. s njim se mogu snimati samo infracrvene fotografije.

\section{Infracrveno LED osvjetljenje}

U kreativnoj i aplikativnoj domeni za potrebe istraživanja $\mathrm{i}$ snimanja $\mathrm{u}$ infracrvenom području uporabljeno je i posebno osvjetljenje. Naime da bi se moglo izvršiti snimanje u infracrvenom području, osim prilagođenog digitalnog fotoaparata potrebno je objekt/e izložiti infracrvenoj svjetlosti te izvršiti snimanje po mraku. Izvori svjetlosti koji omogućuju snimanje u noćnom modu su infracrvene LED diode koje upravo emitiraju svjetlost u spektru koje ljudsko oko ne vidi, slika 5 .

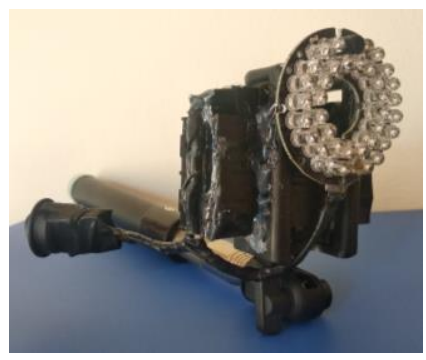

Slika 5. Učenička konstrukcija infracrvenog LED osvjetljenja 
Praktičan rad i dizajniranje neopravdano su zanemareni i izostavljeni unazad niza godina, a značajni su faktori u razvoju učeničkih motoričkih vještina i stjecanja određenih kompetencija. Sekundarni cilj ovog rada je i stjecanje vještina rješavanja problema i razumijevanja svakodnevnih tehnoloških fenomena, kao i estetskih, tehničkih i psihomotoričkih vještina.

\section{Snimanje u vidljivom i infracrvenom spektru}

Nakon prilagodbe i pripremnih radnji učenici su pristupili snimanju objekata, flore i faune te analizi istog. Provođenjem paralelnog snimanja i bilježenja u vidljivom i infracrvenom spektru dobivaju se dvostruke informacije naše okoline (Šipuš i sur., 2014; Žiljak Vujić, 2014). Slika 6 prikazuje izgled objekta u vidljivom i bliskom infracrvenom spektru (NIR) snimljeno običnim i modificiranim digitalnim fotoaparatom.

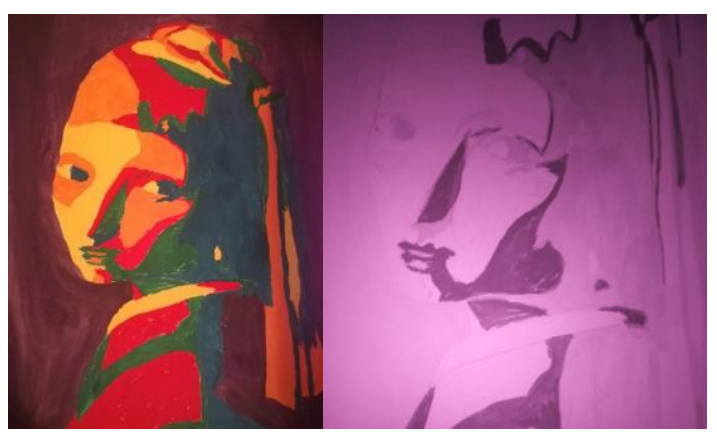

Slika 6. Djevojka s bisernom naušnicom, slika učenice Leonarde Kozarić, snimljena u vidljivom i infracrvenom

Usporedbom dviju snimljenih fotografija $u$ dva različita režima snimanja, vidljivom i infracrvenom, uočava se već na prvi pogled zanimljiva razlika, što je učenike jako iznenadilo. Ovakvim pristupom razmišljanju o prirodi učenici mogu doživjeti radost $\mathrm{i}$ uzbuđenje koje inače prati znanstvena istraživanja. Učenici su analizirali infracrvenu fotografiju i običnu fotografiju. Istraživanje literature in je dovelo do zaključka da se na infracrvenoj slici uočava tzv. prisustvo i odsustvo apsorpcije NIR komponente. Infracrveno zračenje prodire u slojeve slike koje vidljiva svjetlost više ne doseže, a prodire dok ne biva ili apsorbirano ili reflektirano. Odsustvo apsorpcije NIR komponente se uočava na većini boja, žutoj, narančastoj, crvenoj, plavoj i ljubičastoj, a prisustvo samo na zelenoj boji. Učenici su uočili da zelena boja jako apsorbira blisko infracrveno valno područje. Može se još reći i da žuta, narančasta, crvena, plava i ljubičasta reflektiraju infracrveno zračenje, a zelena ga jako apsorbira. To znači da je u mraku slika nevidljiva našem oku ali nije nevidljiva u infracrvenom području, što je jako zaintrigiralo učenike. Učenici su se susreli s pravom problemskom situacijom za koju im nije bila poznata standardna procedura rješavanja. Rješavanje ovog tipa problema od učenika zahtijeva različite razine kreativnosti.

Slika 7 prikazuje papigu i čempres, snimljene u bliskom infracrvenom spektru (NIR). Slika pokazuje da većina boja ne apsorbira NIR valno područje. Papiga i čempres se izvanredno sakrivaju u bliskom infracrvenom spektru, u mraku, jer su poistovjećeni s florom okoline.

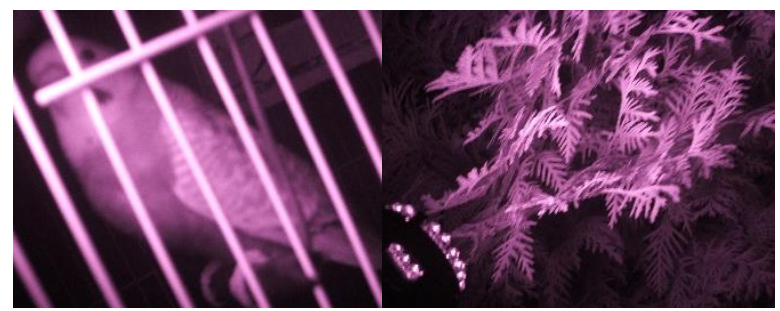

Slika 7. Infracrvena fotografija faune i flore

Razlika vizualne i infracrvene apsorpcije svjetla u flori i fauni omogućuje kamuflaže u kretanju i u okolišu. Na temelju kratke analize apsorpcije i refleksije boja u vidljivom i „nevidljivom“ infracrvenom dijelu spektra učenici su istraživali neke primjere mogućih prirodnih kamuflaža u infracrvenom području spektra (Žiljak Vujić, 2014). Istraživanje kamuflaže u flori i fauni se pokazalo posebno zanimljivo učenicima jer im je pojam kamuflaže poznat ali zapravo potpuno neistražen.

\section{Kamuflaža}

Što uopće znači kamuflaža? Kamuflaža (franc. camouflage); mijenjanje vanjskog izgleda, osobito vojnih objekata kako ne bi bili uočljivi; prikrivanje stvari, događaja ili ponašanja lažnim ili prividnim oblicima. Kamuflaža je način na koji se objekt prikriva. Prikrivanje je važan faktor za opstanak koji je u interesu mnogim oblicima života. Kamuflaža je vezana uz okoliš u kojem biljka ili životinja obitavaju. Kamuflaža može zaštititi biljku ili životinju od potencijalnih predatora, $\mathrm{tj}$. onih koji se nalaze više $\mathrm{u}$ hranidbenom lancu. Stoga su učenici istraživali kako su se biljke i životinje prilagodile modernom okruženju. Isticanje značaja implementacije interdisciplinarnog pristupa u radu $s$ učenicima potiče razvoj međupredmetnih kompetencija, pogotovo u prirodoslovlju. Uobičajeno učeničko okruženje, dominantno frontalni način rada, ne rezultira „izletima“ u međupredmetne teme, pogotovo ne one koje izlaze iz okvira klasične nastave prirodoslovlja.

\section{Flora i fauna u modernom i suvremenom okruženju i njihova kamuflaža}


Biljke su uključene u moderni svijet tako što je određena populacija integrirana kroz parkove, kućne biljke, plantaže, vrtove,... Ondje kamuflaža ne dolazi do izražaja, ali nam omogućuje proučavanje načina na koje su biljke razvile svoju kamuflažu. Životinje su uvedene u moderni čovjekov svijet iz različitih potreba, a manja populacija životinja se samostalno integrirala u čovjekovu okolinu.

$U$ promijenjenoj okolini biljke i životinje se puno teže koriste kamuflažom koju su toliko dugo razvijale. Biljke i životinje se susreću s novim oblicima prijetnje za njihov opstanak. Kako kamuflaža biljaka i životinja funkcionira kao sustav?

\section{Flora u vidljivom i infracrvenom spektru - analiza uzorka}

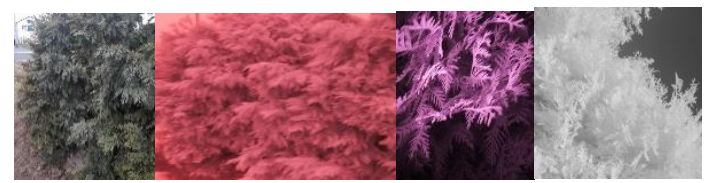

Slika 8. Nutkanski čempresi ispred gradske kuće snimljeni u vidljivom i infracrvenom spektru

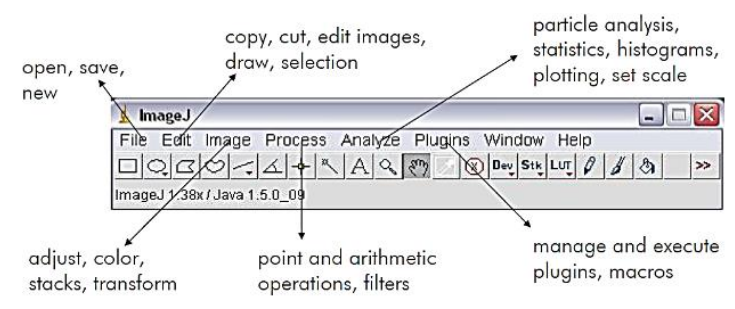

Slika 9. Osnove sučelja programa ImageJ

Na temelju razumijevanja apsorpcije boja u vidljivom i infracrvenom dijelu spektra valnih duljina učenici su pristupili snimanju $u$ vidljivom $i$ infracrvenom području, a nakon toga obradi infracrvene fotografije u nastojanju razumijevanja integracije biljaka i životinja u svakodnevnom okruženju. U svrhu dobivanja specifičnih uzoraka iz naše svakodnevne flore i faune učenici su koristili program ImageJ.

ImageJ je besplatan software za računalnu obradu i analizu digitalne slike. U programu ImageJ učenici su digitalne fotografije obradili kako bi dobili osnovne oblike i jednostavan uzorak kojim se stvara kamuflaža u prirodi. Program je vrlo koristan i obiluje raznim alatima koji omogućuju bolju obradu fotografija i bolje razumijevanje problema (Rasband, 2018). U svrhu „uzimanja kamuflažnog uzorka“ učenici su doradili slike. To podrazumijeva korekciju kontrasta i zasićenosti boja. U postupku obrade snimljenih slika učenici su pojednostavili boje RGB spektra i obradili ih procesom znanom kao i greyscale reproduction. Dobiveni rezultati su vizualno analizirani kako bi se izdvojili zadani oblici. Izdvajanjem sekcije završne slike dolazi se do zaključka. Odabrani primjer Nutkanskog čempresa koji je snimljen i obrađen u programu ImageJ ukazuje da je uzorak na slici 12 osnovni uzorak prirodne kamuflaže čempresa zabilježen u infracrvenom spektru (Friškovec i Gabrijelčič, 2010).

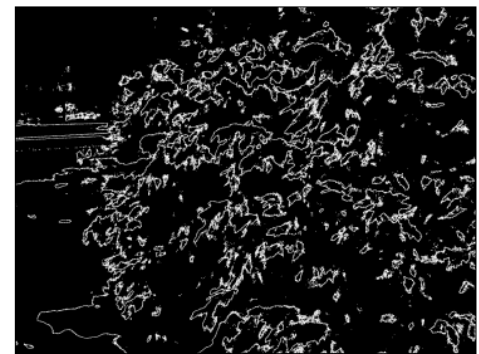

Slika 10. Slika pripremljena u programu ImageJ s definiranim rubovima, Nutkanski čempresi ispred kuće kamuflažnog uzorka čempresa u prirodnom okruženiu

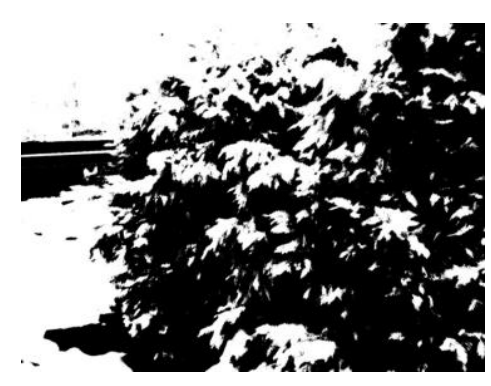

Slika 11. Slika pripremljena u programu ImageJ s izdvojenim oblicima, Nutkanski čempresi ispred kuće

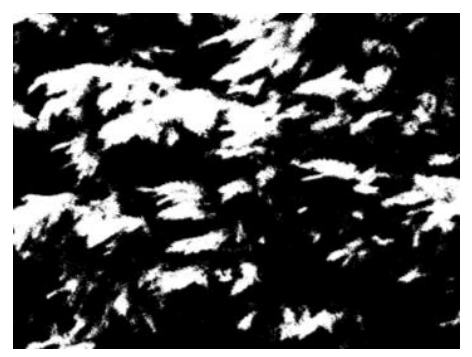

Slika 12. Nutkanski čempresi izdvojena sekcija; isječak

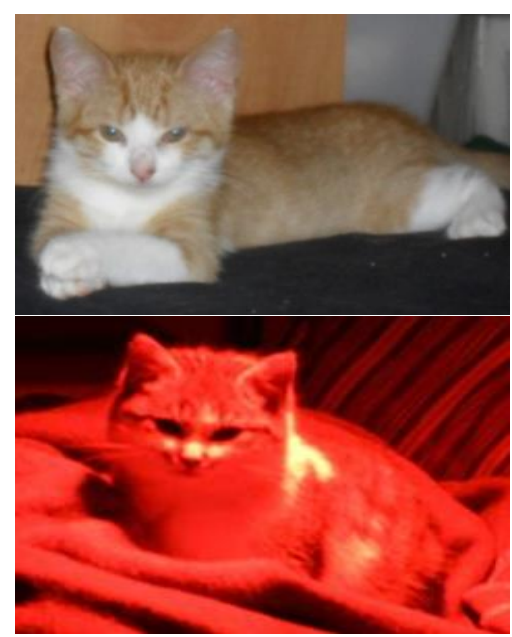

Slika 13. Domaća mačka snimljena u vidljivom i infracrvenom spektru 
Fauna u vidljivom i infracrvenom spektru - analiza uzorka

Kao reprezentativni primjer faune istraživala se domaća mačka. Digitalna fotografija domaće mačke obrađena je u programu ImageJ slijedeći istu proceduru kojom je obrađena slika uzorka Nutkanskog čempresa. Dobiveni snimci vizualno su analizirani.

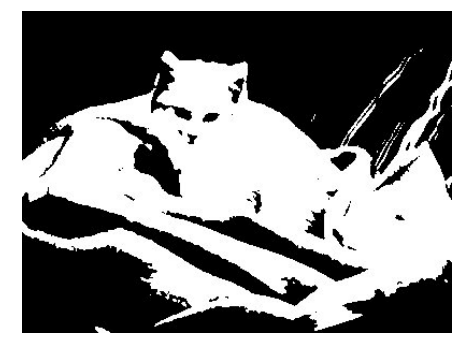

Slika 14. Slika domaće mačke pripremljena u programu ImageJ s izdvojenim oblicima

Slika 16 prikazuje osnovni uzorak prirodne kamuflaže domaće mačke zabilježen $u$ infracrvenom spektru. Kamuflažni uzorak mačke iz primjera ne dolazi do izražaja u infracrvenom spektru. Boja domaće mačke u primjeru je pretežno svjetlo narančasta. Većina takvih bojila ne apsorbira blisko infracrveno valno područje što je uočeno i na slici 6, djevojke s bisernom naušnicom. Mačka se izvanredno sakriva u infracrvenom području u mraku.

Ako se usporede uzorci u vidljivom spektru i $u$ infracrvenom spektru možemo se zaključiti da infracrveni spektar nije svjetlosni spektar u kojem se pojavljuje kamuflaža domaće mačke, slika 17 . Da bi se razumjelo zašto domaća mačka nije razvila kamuflažni uzorak, bilo je potrebno dodatno istražiti i proučiti literaturu iz područja koje istražuje infracrveni dio spektra. Naposljetku se došlo do sljedećih spoznaja, umjesto konusnih stanica koje su zadužene za boje, kojih je mnoštvo u mrežnici ljudskog oka, mačke imaju mnogo više štapićastih stanica koje su zadužene za gledanje u prigušenom svjetlu i odgovorne su za sposobnost noćnog gledanja koje mačke posjeduju. Istražujući nekoliko uzoraka flore i faune u urbanoj, gradskoj okolini, uočila se jednakost apsorpcije bliske infracrvene radijacije (NIR) u cijeloj flori, odnosno kako su se flora i fauna po potrebi kamuflirale vidljivom odnosno nevidljivom, infracrvenom, dijelu spektra (Žiljak Vujić i sur., 2014; Friškovec i sur., 2010).

\section{Zaključak}

Današnji suvremeni odgojno obrazovni proces zahtijeva rapidnu promjenu klasičnog načina poučavanja. Od škole se traži da učenike potakne na svrhovito cjeloživotno učenje. Suvremeni nastavni proces treba u obzir uzeti individualne razlike učenika i njihovih načina učenja te stvoriti okruženje u kojem učenici imaju priliku osjećati se važnima u nastavnom procesu. Jednom kada učenici postanu aktivni sudionici nastave, ravnopravni nastavniku, učenje se tada doživljava kao proces u kojem informacije kolaju u kružnom ciklusu.

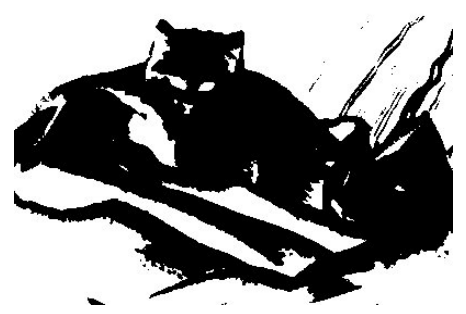

Slika 15. Slika domaće mačke pripremljena u programu ImageJ s definiranim rubovima

Provedbom ovog problemskog i istraživačkog projektnog zadatka trebalo se izbjeći usvajanje sadržaja o svjetlosti, boji i elektromagnetskom zračenju samo na razini definiranja i reproduciranja unutar nastavnog predmeta Fizika, unutar povezanih predmeta okupljenih u prirodoslovlju te rutinsko učenje u spoznavanju pojava svojstvenih svjetlosti. Taj primarni cilj je ostvaren kognitivnim konstruktivizmom. Razvoj znanstvenog znanja kod učenika potaknut je dodatnim otkrićima, u području korelacije fizike $s$ drugim prirodoslovnim predmetima (STEAM), i invencijama koje uključuju nastajanje i evoluciju ideja. Promatranjem i zaključivanjem

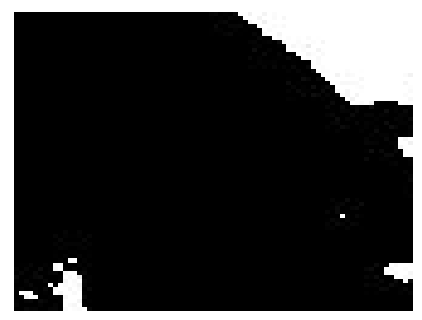

Slika 16. Osnovni kamuflažni uzorak domaće mačke

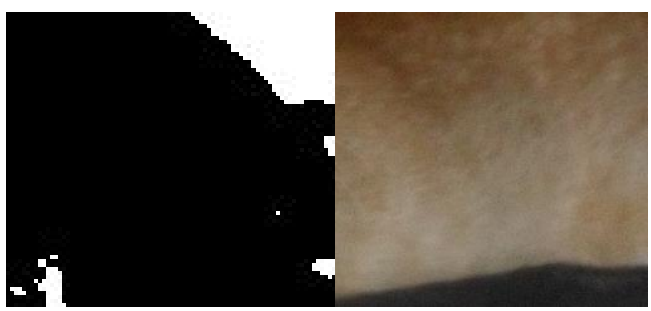

Slika 17. Osnovni uzorak dlake domaće mačke u kamuflažnom infracrvenom i vidljivom dijelu spektra

znanstvenih postupaka učenici razvijaju prirodoznanstvene kompetencije. Kroz navedeni način rada $u$ kojem su upotrijebljene znanstvene metode rada u kombinaciji s proširenim razmišljanjem 
o prirodi, učenici su osjetili radost i uzbuđenje znanstvenog istraživanja. Pozitivna iskustva učenika možemo mjeriti njihovim pojačanim interesom za sudjelovanja na natjecanjima inovatora, natjecanjima i smotrama iz fizike, biologije, informatike, GLOBE programa i slično. Pozitivna iskustva učenika se mjere i postignutim uspjesima iz gore navedenih područja te odabirom studijskih programa koji omogućuju nastavak obrazovanja i specijalizacije u području prirodoslovlja ili STEAM-a. Također, na razini škole, ali i šire, primjećuje se povećan interes šire lepeze sudionika za aktivnijim sudjelovanjem i djelovanjem u nekim novim ne samo projektima nego i svakodnevnom nastavnom procesu. Skupina učenika, koja je sudjelovala u svim fazama ovog školskog projekta, visokomotivirani su učenici s izraženim afinitetima prema fizici i prirodoslovlju.

Potpuno je opravdano uvođenje dodatne izbornosti nastavnih sadržaja u srednjoj školi.

$\mathrm{U}$ ostvarenju navedenih ciljeva pojavljuju se i manjkavosti ili prepreke od kojih su najčešće one organizacijske poput smjenskog rada nastavnika, rasporeda sati, a njih je moguće premostiti upravo uporabom informacijsko-komunikacijskih tehnologija. Učenik u fokusu doživljava pozitivna iskustva učenja u školi koja omogućuje da učenik uči otkrivanjem i stvaranjem, da se sa svojom kreativnošću pozitivno suoči sa svim promjenama na koje će naići. Učenik u fokusu je izazov. Za njega proces učenja treba biti usmjeren na aktivnosti koje u sinergiji provode nastavnik i učenik. Takav način rada sa učenicima ima učinke: funkcionalni transfer znanja, razvijanje međupredmetnih kompetencija realizacijom interdisciplinarnog pristupa u nastavi, učenička znanja nisu segmentirana i podijeljena na "ono što su učili iz fizike ili biologije ili informatike, ...". Radom pod naslovom Fokus na pokus prikazujemo jedan dio kulture učenja, usmjerene protiv tromog znanja, koja se temelji na kooperativno-integrativnim didaktičkim pristupima i konstruktivizmu kao poveznici poučavanja sadržaja prirodoznanstvenih predmeta. Učenik u fokusu treba nastavnika mentora idejnog začetnika.

\section{Literatura}

MZO, (2017). Nacionalni dokument prirodoslovnoga područja kurikuluma. Dostupno na: https://mzo.gov.hr/UserDocsImages/dokumenti/ Obrazovanje/NacionalniKurikulum/PodrucjaKurik uluma/Prirodoslovno\%20podru\%C4\%8Dje.pdf.

Conklin, W. (2007). Applying Differentiation Strategies. Teacher's Handbook for Grades 3-5, Huntington Beach: Shell Education.
Krsnik, R. (2008). Suvremene ideje u metodici nastave fizike. Zagreb: Školska knjiga.

Žarnić, B., Hicela, I., Kelava, M., Tomić Ferić, I. (2002). Edukacija za kritičko i kreativno mišljenje. U: Kvalitetna edukacija i stvaralaštvo, zbornik znanstvenih i stručnih radova (str. 57-75), Dani Mate Demarina (2; 2001, Brijuni) (Tatković, N. i A. Muradbegović, ur.). Pula: Sveučilište u Rijeci, Visoka učiteljska škola u Puli; Zagreb: HPKZ.

MZO, (2019). Odluka o donošenju kurikuluma za nastavni predmet Fizika za osnovne škole i gimnazije u Republici Hrvatskoj, MZO, siječanj 2019. Dostupno na https://narodnenovine.nn.hr/clanci/sluzbeni/2019 $01 \quad 10 \quad 210 . h$ tml.

Henč-Bartolić, V., Kulušić, P. (1991). Valovi i optika. Zagreb: Školska knjiga.

Dimić Vrkić, J. (2007). Socijalni oblik nastavnog radarad u skupinama. Acta ladertina, vol. 4, br. 1, str. 23-34.

Bertman, B. (1970). The ABC's Infrared, Howard W. Sams \&Co. Inc.

Šipuš, M., Ćorić, M., Šutić-Stanić, M. (2014). Infracrvena fotografija. Seminarski rad, Katedra za grafički dizajn i slikovne informacije Grafički fakultet Sveučilišta u Zagrebu, Zagreb.

Žiljak Vujić, J., Rajković, I., Žiljak Stanimirović, I. (2014). Simultano video snimanje $u$ vizualnom $i$ infracrvenom spektru proširene $\mathrm{v} / \mathrm{z}$ stvarnosti. POLYTECHNIC \& DESIGN, vol. 2, br. 1, str. 73-78.

Rasband, W.S. (2018). ImageJ. U. S. National Institutes of Health, Maryland, USA. Dostupno na http://rsb.info.nih.gov/ii/.

Friškovec, M., Gabrijelčič, H. (2010). Development of a Procedure for Camouflage Pattern Design. FIBRES \& TEXTILES in Eastern Europe, Vol. 18, No. 4 (81), str. 68-76.

\section{Experiment in spotlight}

\section{Abstract}

Natural processes are an ideal example of actionoriented teaching that gives students the opportunity to take the initiative in learning where curiosity, creativity, and experimentation with ideas go beyond the set scenario of a traditional teaching topic. If interdisciplinarity and information and communication technologies are included in the process, theoretical concepts become realistic, making it easier for students to understand the real events they witness every day. In our everyday life, we 
observe and experience the state of flora and fauna through the senses of smell, hearing, sight, etc. However, there is the possibility of proving that other information can be experienced in our environment. By parallel recording in the visible and infrared spectrum, we obtain double information about our environment. What do objects and nature look like in the nearinfrared spectrum? The information carried by objects, plants, and living beings in the near-infrared spectrum can be compared to the experience in the spectrum perceived by our eye. There is a correlation of light reflection between visual and infrared absorption. The difference between visual and infrared light absorption on flora and fauna allows camouflage in motion and in the environment. Hiding in flora and fauna is especially interesting. The paper shows the synchronized interdisciplinarity and application of technology in the educational process in which a relationship is established with "real life", the living environment of students, and the interconnectedness of things in life with all other aspects of science, discipline or subject. The result is activities that are carried out in synergy by students of science and mathematics and teachers.

Keywords: visible and infrared spectrum, digital photography, interdisciplinarity, science education. 